\title{
JACQUES LACAN: APROPRIAÇÃO E SUBVERSÃO DA LINGÜÍSTICA
}

Nadiá Paulo Ferreira

Doutora em Letras;

psicanalista do

Corpo Freudiano

do Rio de Janeiro -

Escola de

Psicanálise;

professoratitular

de Literatura

Portuguesa da Uerj.

RESUMO: 0 artigo parte das fontes lingüísticas da teoria de Jacques de Lacan, dando destaque aos conceitos de estrutura, sujeito, signo (Ferdinand de Saussure), metáfora e metonímia (Roman Jakobson), visando demonstrar que as transformações operadas nesses conceitos por Lacan separam de forma irreconciliável a psicanálise da lingüística.

Palavras-chave: Psicanálise, lingüística, estrutura.

ABSTRACT: Jacques Lacan: linguistic appropriation and subversion. The article is based on Lacan's linguistics theory, highlighting the concepts of structure, subject, sign (Ferdinand de Saussure), metaphor and metonymy (Roman Jakobson), aiming to show that Lacan's analysis of these concepts definitely separates psychoanalysts from linguistics.

Keywords: Pschychoanalisys, linguistics, structure.

M eu dizer que 0 inconsciente é estruturado como uma linguagem não é do campo da lingüística.

JACQUES LACAN

$\mathrm{N}^{\mathrm{s}}$

início dos anos 50, a psicanálise, enquanto “método de verdade e de desmistificação das camuflagens subjetivas" (LACAN, 1998, p. 242), estava sendo transformada em uma prática que tinha como finalidade a adaptação do indivíduo ao meio social, desviando-se, assim, da pedra angular dosfundamentos de Freud: o conceito de inconsciente e a teoria sobre a sexualidade. Jacques Lacan, então, aparece com uma proposta de reflexão, a partir de uma nova ciência, a fim de que a experiência psicanalítica seja reconduzida à fala e à linguagem: 
“A lingüística pode servir-nos de guia neste ponto, já que é esse o papel que ela desempenha na vanguarda da antropologia contemporânea, e não poderíamos ficarIhe indiferentes." (LACAN, 1998, p. 286)

Em função desta proposta, Jacques Lacan se apropria de uma série de termos lingüísticos, com indicações das fontes e com homenagens: Ferdinand de Saussure, o fundador da Lingüística, e Roman Jakobson, um dos fundadores do grupo dos Formalistas Russos (1915-1920) eum dos mais importantes participantes do Círculo Lingüístico de Praga ( 1926).

0 objetivo deste artigo é demonstrar que Lacan se apropriou de al guns conceitos lingüísticos, ao invés de importá-los. 0 trabalho de reconstrução desses conceitos orientou, durante trinta anos, seu projeto de ensino: a releitura dos textos freudianos para sal vaguardar a "deterioração do discurso analítico" (LACAN, 1998, p. 245) e para desenvolver o axioma de que o inconsciente é estruturado como linguagem.

\section{O SIGNO, O SIGNIFICANTE E O SIGNIFICADO}

Em “A instância da letra no inconsciente ou a razão desde Freud" (LACAN, 1957/ 1998), para demonstrar queo inconsciente é estruturado como linguagem, Lacan, ao mesmo tempo em que se apropria do conceito de significante formalizado por Saussure, subverte- 0 .

Para Saussure, o signo é produto da articulação de duas instâncias: o significante e o significado. 0 aprisionamento do significante à ordem do significado transparece, nitidamente, na sua concepção de signo: " o signo lingüístico une não uma coisa e uma palavra, mas um conceito e uma imagem acústica" (SAUSSU RE, s.d., p.80). É por acreditar na reciprocidade biunívoca entre significante e significado que Saussure irá procurar as leis que dariam conta da articulação entre essas duas instâncias. E se nada encontra, a arbitrariedade passa a ser um dos princípios que rege o signo lingüístico:

“a idéia de'mar' não está ligada por relação al guma interior à seqüência de sons m-ar $r$ que Ihe serve de significante; poderia ser representada igualmente bem por outra seqüência, não importa qual; como prova, temos as diferenças entre as línguas e a própria existência de línguas diferentes". (SAUSSURE, s.d., p. 81-82)

Para definir a arbitrariedade do signo, ${ }^{1}$ Saussure lança mão de uma metáfora surpreendente: a língua é uma "carta forçada" (SAU SSURE, s.d., p. 85). Para ele,

${ }^{1} \mathrm{Cf}$ o primeiro parágrafo da primeira parte do capítulo II, "Imutabilidade e mutabilidade do signo" do Curso de Lingüística Geral, de Saussure. 
uma das funções da língua é a ligação de uma imagem acústica (massa sonora constituída por fonemas) a uma imagem mental ( significado).

Lacan, ao ler a teoria sobre o valor do signo verbal, tanto na versão de Sechehaye e Bally, ${ }^{2}$ quanto nas fontes manuscritas reunidas por Robert Godel, conclui que não há relação entre significante e significado.

Apesar de Saussure (e também os lingüistas que o sucedem) não abandonar a correspondência entre significante e significado, não há dúvida de que, ao abordar a questão do valor, ele não só privilegia o significante em detrimento do significado, mas também faz questão de diferenciar o significante da imagem acústica: o significante, "em sua essência, (...) não é de modo algum fônico; éincorpóreo, constituído, não por sua substância material, mas unicamente pelas diferenças que separam sua imagem acústica de todas as outras" (SAU SSU RE, s.d., p. 137-138).

Lacan descarta a concepção saussuriana de signo e elabora uma teoria do significante, que tem como ponto de partida o seguinte al goritmo: S/ s. 0 próprio Lacan indica a leitura que deve ser feita do seu algoritmo: "significante sobre significado, correspondendo o 'sobre' à barra que separa as duas etapas" (LACAN, 1998, p. 500). Levar em conta esse traço, dando-Ihe valor de barra, implica privilegiar a pura função do significante em detrimento da ordem do significado.

0 que isso significa? A estrutura do significante se caracteriza pela articulação e pela introdução da diferença que funda os diferentes. U ma série de conseqüênciasé produzida, separando os campos da lingüística e da psicanálise: ${ }^{3}$

1. 0 privilégio do significante em detrimento do significado.

2. O significanteé puro non sensee não tem relação com o significado, o que equivale a dizer que o significante não significa nada ou pode significar qualquer coisa.

3. A oposição entre significante e significado marcada pela barra coloca 0 significável ${ }^{4}$ submetido ao significante.

\footnotetext{
${ }^{2}$ A primeira publicação do Curso de Lingüística Geral, em 1916, é resultado das anotações reuni das por Charles Bally e Albert Sechehaye, com a colaboração de Albert Riedlinger, dos três cursos de Linguística Geral, dados por Saussure na Universi dade de Genebra (de janeiro a julho de 1907, de novembro de 1908 a julho de 1909, e de outubro de 1910 a julho de 1911).

${ }^{3} \mathrm{Não}$ há leitura sem interpretação e sem implicação do sujeito com a verdade. A repetição do que está escrito e consagrado indica uma escolha ética, que aponta para o lugar de um sujeito na estrutura do discurso, independente desse lugar ser ou não reconhecido por ele. 0 escrito e o consagrado não são a mesma coisa. Os pós-freudianos consagraram uma leitura dos escritos de Freud, que foi interpretada por Lacan como adulteração da teoria freudiana. Donde se conclui que o mais relevante incide sobre as coordenadas que servem de subsídios à interpretação das fontes. Nesse sentido, esse artigo é uma leitura da teoria do significante, elaborada por Lacan, que parte de algumas premissas, das quais se destaca a não relação entre significante e significado.

${ }^{4}$ Significável não é empregado como conceito. Apesar de não estar registrado nos principais dicionários da língua portuguesa, utilizei este termo como adjetivo, isto é, como forma nominal que se associa com o substantivo, no caso, com o vocábulo significado. Significável deve ser
} 
4. 0 que faz parte da própria estrutura do significante é a conexão com outros significantes formando uma cadeia: " 0 significante como tal não se refere a nada, a não ser que se refira a um discurso, quer dizer, a um modo de funcionamento, a uma utilização da linguagem como liame" (LACAN, 1982, p. 43).

5. Só pode haver articulação entre os significantes porque eles podem ser reduzidosa puros elementos diferenciais.

6. A organização dos significantes se faz através de duas operações, que são as mesmas da linguagem: condensação (Verdichtung) e deslocamento (Verschi ebung), cujos efeitos são a metáfora e a metonímia.

7. A ordem do significado é efeito da cadeia do significantee, justamente por isto, é na cadeia do significante que o sentido insiste. A significação não está, portanto, em nenhum elemento particular da cadeia. 0 deslizamento incessante do significado sob o significante, por ação do inconsciente, não quer dizer que não haja a prevalência de um sentido em jogo. Lacan faz questão de pontuar que seria um erro " pensar que a significação reina irrestritamente para-além. Pois o significante, por sua natureza, sempre se antecipa ao sentido, desdobrando como que adiante dele sua dimensão" (LACAN, 1998, p. 505). É precisamente no significável que se engendra a paixão pelo significado. A fascinação por certas metáforas cristaliza o sentido, emperrando o deslocamento (Verschiebung) metonímico dos significantes na cadeia. Do congelamento do significante nasce não só a paixão pelo sentido que, inevitavelmente, surge sob a forma de um bem como ideal, mas também 0 aprisionamento do sujeito ao gozo retirado desse sentido cristalizado, obstaculizando o processo de si gnificação e a posição do sujeito em relação ao desejo. 8. A articulação significante não se produz sozinha, é necessário que haja um sujeito. 0 significante só pode passar para o plano da significação porque há um sujeito operando a cadeia do significante. Essa relação do sujeito com o significante é denominada de relação fundamental.

Na versão do Curso de Lingüística Geral, precisamente no capítulo sobre o valor do signo lingüístico, o significante não se confunde com os fonemas. Ao contrário deles, como já assinalamos anteriormente, ele não tem nem forma nem substância. Essa diferença entre significante e imagem acústica (um conjunto articulado de fonemas) deve ser bem enfatizada, para que não ocorra a adulteração do ensino que Saussure exerceu com tanto rigor na Universidade de Genebra. Os fonemas não são a variedade modulatória dos sons. Um fonema é um som único, cujos

lido, então, como sinônimo de significado: em que há ou denota significação. Sabemos que entre vários sinônimos há sempre um que se impõe, conforme o contexto, por ser o que melhor expressa 0 que se quer dizer e transmitir. Nesse sentido, escolhi o termo significável para eliminar qualquer relação com o conceito saussuriano de significado e, assim, enfatizar o que considero fundamental na teoria de Lacan sobre o significante: “( ...) o significante só se coloca como não tendo nenhuma relação com o significado" (LACAN, 1982, p. 42). 
traços distintivos marcam a sua diferença em relação a outras unidades mínimas desom.

Outras características básicas dos fonemas para Saussure poderiam ser resumidas: 1. O seu número élimitado e sua quantidade varia de uma língua para outra.

2. São formas regidas por leis de um sistema fechado que fazem parte da estrutura deumalíngua.

3. São de natureza auditiva e por isto têm as mesmas características do tempo: cada fonema representa uma extensão que só é mensurável numa dimensão.

Os fonemas assim definidos são o suporte material do significante. A materialidade do significante determina outra lei que rege o signo lingüístico: o princípio de linearidade. Essa lei é o limite que o significante verbal recebe do tempo, ou seja, só se pode falar uma palarra de cada vez, uma depois da outra. Os traços diferenciais que comparecem numa imagem acústica são a sua face significante. E imagem acústica é a massa sonora produzida pela combinação de fonemas. A palavra dia, por exemplo, se opõeà palavra noite, não só pelo seu significado, mas sobretudo porque sua imagem acústica é diferente de noite e de todas as outras imagens acústicas da língua portuguesa. A diferença significante éo que Saussure denomina de oposição por negatividade.

Se Lacan toma emprestado de Saussure o conceito de significante para romper com a tradição estruturalista, é óbvio que uma nova concepção de signo terá lugar no seu pensamento. Signo éo que representa algo para al guém. 0 signo não implica o aparecimento do significado, porque colocar em cena um sentido é função do significante. No Seminário 9, L'identification (1961-1962, inédito), Lacan diferencia o signo do significante da seguinte forma: a pegada de um passo diante de Robinson Crusoé tem valor de signo, porque representa para ele alguma coisa com valor de símbolo, podendo Ihe dar significantes. Justamente por isto, ele pode chegar à conclusão de que não está só na ilha. A distância entre este signo ( pegada) e o que advém como instrumento da negação (não estou só) são os dois extremos da cadeia. É entre estas duas extremidades que o sujeito pode surgir, já que seu aparecimento está sempre ligado a uma pulsação em eclipse: o que comparece numa fal a para desaparecer e de novo reaparecer. Símbolo, aqui, deve ser entendido não como significado, mas alguma coisa com valor de signo, isto é, com valor dedons.

"Pois esses dons já são símbolos, na medida em que símbolo quer dizer pacto e em que, antes de mais nada, eles são significantes do pacto que constituem como significado: como bem se vê no fato de que os objetos da troca simbólica - vasos feitos para ficar vazios, escudos pesados demais para carregar, feixes que se ressecarão, lanças enterradas no solo - são desprovidos de uso por destinação, senão supérfluos por sua abundância." (LACAN, 1998, p. 273) 
Os primeiros atos e os primeiros objetos de uma criança engendram, nesse sentido, símbolos (signos) com valor de dons. Na constituição de um símbolo, 0 que está em jogo é um conceito. É o conceito que engendra a coisa, enão o contrá rio. 0 conceito éa própria coisa, o que implica dizer que a coisa se reduz ao nome. É porque houve a produção de símbolos com valor de dons que haverá o ingresso no mundo das palavras, onde será criado o mundo das coisas.

0 famoso exemplo do neto de Freud 5 ilustra bem o que seria esse ingresso no mundo das pal avras, onde se cria o mundo das coisas. No jogo do carretel, as palavras balbuciadas (fort / da) já se organizam em torno do par presença e ausência.

Diacronicamente, temos as leis da linguagem concretizadas numa determinada língua. Sincronicamente, temos o jogo do carretel, seguido de duas palavras, indicando a aquisição pelo sujeito do par opositivo de fonemas que recebe de sua língua materna. É a assimilação da estrutura sincrônica que indica a integração do sujeito na diacronia.

Mas essa brincadeira com o carretel implica a destruição do objeto, uma vez que consiste em fazê-lo aparecer e desaparecer. Essa destruição do objeto indica o desaparecimento do sujeito (afânise), já que ele se toma como objeto, indicando assim o modo pelo qual se real iza a primeira manifestação do símbolo. Diz Lacan: "o símbolo se manifesta inicialmente como assassínio da coisa, e essa morte constitui no sujeito a eternização de seu desejo" (LACAN, 1998, p. 320).

É na alternância de presença e ausência que temos a constituição de traços que, para Lacan, são o rastro de um nada em torno do qual se engendra o sentido. É no uso de uma língua que se abre para o sujeito a possibilidade de múltiplas substituições e combinações, que irão determinar o seu destino e revel ar, em uma análise, a sua posição na fantasia.

\section{A LINGUAGEM}

Assim como Lacan ${ }^{6}$ se apropriou do significante saussuriano, faráo mesmo com a concepção delinguagem, identificando as origens do estruturalismo no formalismo russo.

Roman Jakobson, no texto "Dois aspectos da linguagem e dois tipos de afasia", 7 define a linguagem a partir de duas operações, que presidem todo ato de fala: a seleção e a combinação. Essas operações engendram uma série de procedimentos comuns em todas as línguas:

1. A seleção de palavras e de outras entidades lingüísticas se realiza através de associações feitas por identidade (semelhança) e por oposição ( diferença). Essas relações

\footnotetext{
${ }^{5}$ Cf. o texto de Freud "Além do princípio do prazer" (1920).

${ }^{6}$ Cf. o texto "Subversão do sujeito e dialética do desejo no inconsciente freudiano" (1960), em Escritos.

${ }^{7}$ Este texto se encontra no livro Lingüística e comuni cação, de Roman Jakobson.
} 
de associação são chamadas de similaridade. Seleção e substituição "são as duas faces de uma mesma operação" (JAKOBSON, s.d., p. 40).

2. A combinação de unidades lingüísticas já selecionadas cria um contexto, estabelecendo um modo de organização, em que a posição de um significante em relação aos outros determina a produção do sentido. Essas relações de concatenação são chamadas de contigüidade. Combinação e contextura "são as duas faces de uma mesma operação" (JAKOBSON, s.d., p.40).

Essas duas operações de linguagem engendram dois eixos e dois processos:

1. Os eixos do paradigma ( sel eção / substituição / relações de similaridade) e do sintagma (combinação/ contextura/ relações de contigüidade);

2. Os processos metafórico e metonímico.

A metáfora se produz pelas relações de similaridade assim como a metonímia pelas relações de contigüidade. Jakobson, quase no final do seu artigo, se refere ao trabalho de Freud sobre os sonhos, identificando as relações de contigüidade com a transferência metonímica e com a condensação sinedóquica e as relações de similaridade com a identificação e o simbolismo.

Lacan, interpretando Jakobson, define a metáfora e a metonímia como sentidosfigurados, que se originam das operações de substituição (metáfora) e de combinação (metonímia) e estabelece as seguintes correspondências com Freud: a metáfora com a condensação e a metonímia com o deslocamento.

Para Lacan, ao contrário de Jakobson, não há metáfora sem metonímia e viceversa. ${ }^{8}$ Toda metonímia é efeito de uma operação metafórica interrompida por ação do recal que, assi $m$ como toda metáfora é efeito de uma operação metonímica. Essa sobredeterminação se sustenta na produção de uma metáfora inaugural, queé a base, o suporte, dessas duas técnicas do significante, que são a metáfora e a metonímia. 0 Nome-do-Pai, como o "significante que representa a existência do lugar da cadeia significante como lei" (LACAN, 1999, p. 202) é o agente dessa operação. Esse significante é transmitido pelo desejo da mãe:

"A ausência da mãe ou sua presença oferecem à criança - colocada aqui como termo
simbólico, não se trata do sujeito - , pela simples introdução da dimensão simbólica,
a possibilidade de ela ser ou não uma criança demandada." (LACAN, 1999, p. 284)

Eisuma das faces da castração: Nome-do-Pai, sintoma, sujeito barrado e desejo

\footnotetext{
${ }^{8}$ Para Jakobson, um discurso pode se realizar em duas linhas semânticas diferentes. Um tema remetendo para outro tema por similaridade ( processo metafórico) ou por contigüidade ( processo metonímico). Ele identifica um predomínio da metáfora na poesia, nas canções líricas russas, no Romantismo, no Simbolismo, no Surrealismo e nas montagens cinematográficas de Charlie Chaplin e Eisenstein e um predomínio da metonímia na prosa, na epopéia heróica, no Realismo, no Cubismo e nas montagens cinematográficas de D. W. Griffith.
} 
se constituem pela inauguração da primeira metáfora. Entretanto, o desejo, depois de constituído pelo representante do Outro, ou seja, pelo desejo da mãe enquanto portadora do Nome-do-Pai, isto é, da Lei, só pode se manifestar pelavia da metonímia.

Outra distinção fundamental em relação à lingüística diz respeito à função da linguagem. Enquanto para a lingüística a função da linguagem é a comunicação, para a psicanálise é a evocação. A fala como ato de discurso, e não como ato de fonação, implica sempre dirigir uma mensagem para alguém, demandando uma resposta. N este sentido, é através da fala que se real iza a função da linguagem.

Toda fala se caracteriza pelo aqui-e-agora, inscrevendo-se na sincronia, isto é, no eixo das simultaneidades, das relações entre elementos coexistentes, em que se exclui a intervenção do tempo. Mas a fala como ato de discurso apresenta também uma textura do significante e, como tal, se inscreve na diacronia, isto é, no eixo das sucessões, no qual se inclui a intervenção do tempo e as transformações.

Se na fala como ato de discurso se realiza o entrecruzamento da sincronia com a diacronia, cabe, então, perguntar o que para a psicanálise é o discurso? É o efeito da articulação entre língua e linguagem e, como tal, étrans-individual.

É nesse sentido que o inconscienteé o discurso do Outro. 0 inconsciente participa do Outro, enquanto lugar de engendramento do discurso, do sujeito e do desejo. Há, portanto, um discurso que circula e que antecede a constituição de qualquer sujeito. Esse discurso, que o sujeito recebe do Outro, irá fazer parte de sua história. É justamente por isso que o sujeito recebe sua mensagem de forma invertida.

A liberdade de todo sujeito está demarcada pelo limite imposto pelas leis da linguagem e por um discurso que irá inscrevê-lo no desejo do Outro (desejo da mãe enquanto portadora do Nome-do-Pai).

0 inconscientenão está alhures, ele se situa no mesmo lugar dos significantes ( lugar do Outro). E, justamente por isto, podemos defini-lo como uma cadeia de significantes que se repete e insiste em interferir no discurso. 0 inconsciente é o que comparece na fal a como dito que escapa à intenção do dizer e o que estrutura os processos de elaboração onírica, fazendo com que o sonho se apresente para seu autor como enigma a ser decifrado. Nesse sentido, o inconsciente é a outra cena desse Lugar (Outro) em que se produz uma escrita.

\section{A LETRA E OTRAÇO UNÁRIO}

Lacan, num primeiro momento, denomina a materialidade do significante de letra. Esta, como estrutura localizada do significante, apresenta duas propriedades, que se inscrevem em duas dimensões: na sincronia, temos um sistema sincrônico de acoplamentos diferenciais ( imagem acústica); e, na diacronia, temos a cadeia do significante. A letra como materialidade éa essência do significante enquanto traço, é o suporte material do discurso. 
Lacan, quando se refere ao texto A interpretação dos sonhos ( 1900) ${ }^{9}$ faz questão de assinalar que o que está jogo, neste texto, éa letra em sua textura eem seus empregos. As imagens do sonho têm valor de significante e, como tal, nada têm a ver com o significado. É na letra que encontramos o emprego do significantee, justamente por isto, Freud, nesse texto, não só aponta para a valorização das leis da linguagem (lógica do significante) mas também para o uso da letra como hieróglifo.

No Seminário 9, L'identification (1961-1962), Lacan desenvolve o traço unário a partir do conceito de letra, como suporte material do significante. Aqui, fica clara a releitura do texto Psicologia das massas eanálise do eu (1921) a partir da teoria lingüística de Saussure.

Nesse texto, ${ }^{10}$ Freud se refere a uma identificação parcial. 0 sujeito se identifica não com o objeto, mas com al guns de seus traços, os quais são retirados e incorporados por ele. É claro que esses traços do objeto têm para o agente dessa operação valor de ideal. Essa identificação do sujeito não se dirige ao outro como objeto das pulsões sexuais, mas como objeto do amor. Esses traços serão o suporte da constituição de um novo ideal-do-eu (Ich-I deal). Freud ilustra esse processo, referindo-se às relações do homem com as massas artificiais: a I greja e o exército.

Saussure, quando define os fonemas como sendo a materialidade do significante verbal, faz questão de ressal tar a distinção conceitual entre fonema, traços distintivos e significante. Os fonemas são formas mínimas de som que apresentam um conjunto de traços distintivos, os quais, por sua vez, são os respon sáveis pela marcação da diferença, que tem como efeito a oposição entre os fonemas.

$\mathrm{Na}$ língua portuguesa, por exemplo, o fonema t se opõe a todos os outros fonemas em função de três traços distintivos: articulação da ponta da língua com a parte interna da arcada dentária superior ( fonema dental); interrupção momentânea da corrente de ar, determinada pela oclusão da cavidade bucal nesse ponto ( consoante oclusiva); e abertura da glote, impedindo a vibração das cordas vocais. Um significante verbal é constituído por um conjunto articulado de fonemas (ima-

\footnotetext{
${ }^{9}$ Cf. o texto "A instância da letra no inconsciente ou a razão desde Freud" (1957), que se encontra em Escritos (1998).

10 Psicologia das massas eanálise do eu, 1920-1921, é, sem dúvida, o texto mais importante de Freud, no que diz respeito à diferença entre eu-ideal e ideal-do-eu. A identificação do eu e a substituição do ideal do eu pelo objeto apontam, entre outras coisas, para a distinção entre o amor, como sentimento da paixão, e a identificação parcial, no que diz respeito à escolha de objeto, às vicissitudes das pulsões sexuais e ao narcisismo. Quanto a este último, é imprescindível a leitura do texto freudiano Luto emelancolia (1915-1917). Em Psicologia das massas eanálisedo eu, Freud estabelece a distinção entre a identificação parcial e o amor como sentimento da paixão, nomeado por ele "fascinação" e "servidão amorosa", da seguinte forma: "no caso da identificação o objeto desaparece ou fica abandonado e é reconstruído depois no eu, que se modifica parcialmente, conforme o modelo do objeto perdido. No outro caso, o objeto subsiste, mas é dotado de todas as qualidades pelo eu e à custa do eu" (FREUD, 1973, p. 2.590. v. III).
} 
gem acústica), sendo que cada fonema porta um conjunto de traços, os quaisirão demarcar a distinção opositiva e diferencial entre eles.

É bom lembrar, mais uma vez, que o significante não se confunde com o material de que é feito, e o que determina a função significante, instaurando a oposição, éum conjunto de traços distintivos.

Para Lacan, o traço unário (Einzinger Zug) não se confunde com o significante, mas é nele que se sustenta a função significante como diferença pura. N este sentido, é no traço unário (Einzinger Zug), como a forma mais simples de marca, que se situa a origem do significante.

A retirada de uma marca como traço do campo do Outro inaugura a primeira metáfora do sujeito enquanto desejante, sem a qual não haverálugar para o advento de um sujeito cindido. Em relação a essa identificação, diz Lacan:

“O traço unário não está no campo primeiro da identificação narcísica, ao qual Freud relaciona a primeira forma de identificação (...) 0 traço unário, no que o sujeito a ele se agarra, etá no campo do deséo, o qual só poderia de qual quer modo constituir-se no reino do significante, no nível em que há relação do sujeito ao Outro. É o campo do Outro que determina a função do traço unário, no que com ele se inaugura um tempo maior da identificação na tópica então desenvolvida por Freud - a saber, a idealização, o ideal do eu." (LACAN, 1988, p. 242) ${ }^{11}$

\section{A LETRA E A ESCRITA}

Já em outro momento de seu ensino, ${ }^{12}$ a letra se refere a dois efei tos do discurso: o liame e a escrita: "O liame (...) é um liame entre aqueles que falam" ( LACAN, 1982, p. 43) ea escrita “não é de modo algum do mesmo registro, da mesma cepa, se vocês me permitem esta expressão, que o significante" (LACAN, 1982, p. 41).

\footnotetext{
${ }^{11}$ Em relação ao ideal-do-eu, Lacan acrescenta:

"É no entrecruzamento pelo qual o significante unário vem funcionar aqui no campo do Lust quer dizer, no campo da identificação primária narcísica, que está a mola essencial da incidência do ideal do eu. Descrevi em outro lugar a visada em espelho do ideal do eu, desse ser que ele viu primei ro aparecer na forma de um dos pais que, diante do espelho, o segura. Ao se agarrar à referência daquele que o olha num espelho, o sujeito vê aparecer, não seu ideal do eu, mas seu eu ideal, esse ponto em que ele deseja comprazer-se em si mesmo.

É aí que está a função, a mola, o instrumento eficaz que constitui o ideal do eu. Não faz muito tempo, uma menininha me dizia gentilmente que já era hora de al guém se ocupar dela para que ela parecesse amável a si mesma. Ela fazia, assim, a confissão inocente da mola que entra em jogo no primeiro tempo de transferência. 0 sujeito tem uma relação a seu analista cujo centro está no nível desse significante privilegiado que se chama ideal do eu, na medida em que, dali, ele se sentirá tão satisfatório quanto amado." (LACAN, 1988, p. 242).

12 Cf. o Seminário 18, D'un discours qui ne serait pas du semblant (1970-1971) e o Seminário 20, M ais ainda (1972-1973).
} 
Aqui, a dimensão do significante se inscreve no campo da fala, o que faz com que o significante seja reduzido à sua natureza auditiva, onde o que conta são os fonemas como elementos diferenciais. Justamente por isto, "o significante só se coloca não tendo nenhuma relação com o significado" (LACAN,1982, p. 42). Mas apesar disso ou por causa disso, é no discurso que os significantes se amarram, produzindo como efeito dessa amarração o significado. 0 significado atribuído a um significante é literalmente efeito do discurso, isto que faz laço entre os seres falantes.

Cabe, então, perguntar o que em um discurso se produz como efeito da escrita e não da fala? É a letra que, aqui, deve ser compreendida como sendo a gramática do discurso, ou seja, o que só se revela por escrito. Nesse sentido, a escrita é definida como "um outro efeito da linguagem" (LACAN, 1982, p. 63). Equal seria esse outro efeito da linguagem? É precisamente o que vem em suplência ao não- haver da relação sexual. A escrita, então, como um dos efeitos da linguagem, tem a mesma função que a barra tem no algoritmo do significante $(S / S)$ :

"A barra, como tudo que é da escrita, só tem suporte nisto - o escrito não éalgo para ser compreendido." (LACAN, 1982, p. 48)

"Se não houvesse essa barra, com efeito, nada poderia ser explicado, da linguagem, pela lingüística. Se não houvesse essa barra acima da qual há significante passando, vocês não poderiam ver que há injeção de significante no significado. (...) Tudo queé escrito parte do fato de que será para sempre impossível escrever como tal a relação sexual. É daí que há um certo efeito do discurso que se chama a escrita." (LACAN, 1982, p. 48-49)

Assim, a letra, tomada ao pé da letra, é efeito do discurso que só comparece na escrita. Énesse sentido que Lacan define a letra como um ajuntamento de caracteres:

A letra "é o que está impresso no texto da edição definitiva à qual os autores - como vocês sabem, eles são múltiplos - acabaram por dar assentimento. Eles tomam mesmo 0 cuidado de dizer que as letras designam ajuntamentos. Aí é que está a timidez deles, e seu erro - as letras constituem os ajuntamentos, as letras são, e não designam, esses ajuntamentos, elas são tomadas como funcionando como esses ajuntamentos mesmos." (LACAN, 1982, p. 65)

Essas definições da letra não se excluem e se assentam nos aforismos que percorrem toda a trajetória do ensino de Lacan: 0 inconsciente é estruturado como uma linguagem, e esta é o que vem em suplência à impossibilidade de se escrever a relação sexual. É nesse sentido que no Seminário 20, Maisainda (1972-1973) Lacan 
afirma que "o inconsciente é estruturado como os ajuntamentos de que se tratam na teoria dos conjuntos como sendo letras" (LACAN, 1982, p. 66).

\section{O SUJ EITO}

Lacan, ao trazer o significante para o campo da experiência analítica, inclui uma nova concepção de sujeito, que não tem lugar nem em Saussure, nem nos seus discípulos, e muito menos nas novas correntes lingüísticas que surgiram. Para 0 saber lingüístico a noção de sujeito se refere, dependendo do autor, às categorias de pessoa, de indi víduo, de locutor e de emissor.

A categoria de sujeito, introduzida por Lacan, é totalmente estranha ao raciocínio lingüístico e se baseia em uma teoria sobre a estrutura da subjetividade humana: falta-a-ser. Quando nasce uma criança, se houver a inscrição do si mbólico no seu corpo (campo do Outro como lugar dos significantes), produzir-se-á o surgimento de um sujeito e de sua dependência (alienação) à ordem do significante, inaugurando o desejo do homem como desejo do desejo do Outro.

Significante então passa a ser definido como o que representa um sujeito, enquanto diferença, para outros significantes. Esujeito deve ser compreendido como o lugar que se produz no intervalo entre o significante $U m\left(S_{1}\right)$, que é aquele que marca um sujeito, constituindo sua singularidade, e os outros significantes $\left(S_{2}\right)$, que têm como função representá-lo para outros significantes.

Nesse sentido, o significante é signo de um sujeito. É a inscrição na ordem do significante (campo do Outro) que permite a um sujeito operar com as leis da linguagem e produzir significações que escapam à intenção do dizer.

Fica, então, a questão: como um sujeito pode se representar como significante para outro significante? Só na posição de objeto. Representar-se dessa forma implica que o sentido produzido pela função significante se relacioneà imagem que o sujeito tenha de si mesmo. Essa imagem especular nada mais é do que a representação de um sujeito sob a forma de ego. Eis o sujeito comparecendo no registro imaginário sob a forma de objeto a, cuja escrita éi (a).

Depois de incorporar o conceito de linguagem de Jakobson para, mais uma vez, apontar, na descoberta de Freud, a estrutura da linguagem no regime do inconsciente, coloca uma questão que separa sem reconciliação o saber lingüístico da psicanálise. Diz Lacan: "U ma vez reconhecida a estrutura da linguagem no inconsciente, que tipo de sujeito podemos conceber-Ihe?" (LACAN, 1998, p.814).

Não há, na práxis do lingüista, o pressuposto de que toda a experiência do inconsciente reside no entrelaçamento entre sujeito e significante. Não há, também, o inconsciente como ordem do não-sabido, do que não pode ser escrito, do que é um lugar barrado. Há um inconsciente que se apresenta como sinônimo da enunciação, que se inscreve de forma subjacente no enunciado.

Para a psicanálise, só há inconsciente porque há um lugar, o lugar do Outro 
(A), enquanto um campo ondese articulam os significantes que preexistem à constituição de cada sujeito.

Um sujeito, assim constituído, apresenta como singularidade a impossibilidade de ter acesso ao significante que Ihe deu origem $\left(\mathrm{S}_{1}\right)$. Esse significante, que está permanentemente se deslocando sob a cadeia do significante, terá sempre para 0 sujeito valor dex e, como tal, irá proliferar significação.

Este hiato entre o significante primordial, que é do sujeito, e os outros significantes, que irão representálo para outros significantes, tem a mesma função quea barra entre o significante e o significado, no algoritmo que escreve a função do significante.

É essa posição intervalar do sujeito que produz os lapsos e os atos fal hos no discurso. São efeitos do inconsciente estruturado como linguagem o que se diz sem querer dizer. Eisto não é outra coisa senão a produção de um saber que não se sabe. É precisamente nos tropeços de uma fala que "a análise revela a verdade dessa relação, ao fazer dos furos do sentido os determinantes de seu discurso" (LACAN, 1998, p. 815).

A linguagem, justamente isto que divide e articula os pensamentos, inscreve-se no pré-consciente e os pensamentos se inscrevem no inconsciente. É porque há linguagem que o inconsciente e alíngua existem. E, por causa disto, o fal ante pode se servir da língua para significar o que, do ponto de vista da própria língua, não faz sentido.

\section{A EXCLUSÃO DO REAL NO CONCEITO DE ESTRUTURA}

Nesse caminho de apontar as diferenças entre a lingüística e a psicanálise, quero ressaltar que, além da exclusão do sujeito, o real como impossível não faz parte do conceito lingüístico de estrutura.

Da exclusão do real, engendra-se um conceito de estrutura ligado à idéia de total idade. Benveniste ${ }^{13}$ define estrutura como "o arranjo de um todo em partese a solidariedade demonstrada entre as partes do todo, que se condicionam mutuamente" (BENVENISTE, 1988, p. 9. v.1). Essa noção de estrutura produz um saber que acredita dar conta de todos os tipos de relações inerentes às particularidades de um sistema. Por isso, Benveniste pôde afirmar que em cada língua o que está em jogo é uma estrutura, "onde cada peça recebe a sua razão de ser do conjunto que serve para compor" (Idem).

0 calcanhar-de-aquiles dos lingüistas é a homonímia. Mattoso Camara Jr. ${ }^{14}$ define homonímia "como a propriedade de duas ou mais formas, inteiramente distintas pela significação ou função, terem a mesma estruturafonológica" (CAMA-

${ }^{13}$ Cf. Problemas de Lingüística Geral.

${ }^{14}$ Cf. o Dicionário de Linguíística e Gramática. 
RA JR., 1986, p. 139). Ele dá o seguinte exemplo: “ um homem são/ São Jorge/ são várias as origens". Nestes sintagmas, uma mesma imagem acústica corresponde a três morfemas gramaticais (adjetivo, substantivo e verbo), o que implica significados totalmente distintos.

O lingüista só pode dar conta da homonímia identificando al guma coisa que não está funcionando bem na estrutura da língua. Por isso, Mattoso Camara Jr. afirma que a homonímia é "uma deficiência do princípio geral da distinção fonológica" (CAMARA JR., 1986, p. 139). Dessa ficção do todo nasceu o esperanto como esperança de uma língua perfeita, que se poderia tornar universal para todos osfalantes.

Para a psicanálise, o real tem como estatuto o impossível e se inscreve na estrutura sob a forma de um buraco, que comparece como furo real no imaginário ( ausência de um saber, ou seja, de instinto) e como falta de U m significante no simbólico (campo do Outro).

Da relação que se estabelece entre o recém-chegado ao mundo e o representante do Outro (desejo da mãe) opera-se a constituição do sintoma (sinthome) humano, cuja escrita é $S(A),{ }^{15}$ e a exclusão de um resto de gozo. A letra minúsculaa éo recurso utilizado por Lacan para escrever esse resto que ficou sem ser simbolizado e, justamente por isso, se torna o sustentáculo de toda ação desejante.

Desejar está sempre articulado a esse resto não simbolizável. Por isso, desejar é sempre diferente do que se experimenta como realização de um desejo, porque só há para desejar o que fal ta. E quem sustenta o desejo como ação desejante é a fantasia: $s \triangleright a$.

Sal vador Dalí elucida esta fórmula de Lacan, quando numa entrevista, em que os repórteres insistiam - como insistem até hoje - em dizer que a sua obra é delirante - delirante aqui no sentido de tudo aquilo que escapa aos cânones do senso comum - responde, mais ou menos, assim: - "Eu existo porque deliro. Eu deliro porque existo." É óbvio que aqui o verbo delirar tem para o artista o sentido preciso que a fantasia recebe na escrita de Lacan.

\section{O REAL, O GOZO E O SIGNIFICANTE}

Deixei em suspenso a questão crucial para a psicanálise: qual seria o significante que falta no campo do Outro? É o falo: o significante que engendra a barra no al goritmo do significante, no campo do Outro e no advento de um sujeito.

0 real não é o que comparece na estrutura como aquilo que faz buraco no simbólico e no imaginário? 0 falo como objeto não tem representação no campo do Outro. 0 representante dessa falta de representação é o falo como significante.

$15 \mathrm{~S}(\mathrm{~A})$ deve ser lido como a falta de Um significante no campo do Outro e, justamente por isto, se diz que o Outro é barrado. 
A função do significante falo é simbolizar a ausência do objeto do desejo. É neste sentido que o falo éo significante do desejo humano.

É importante não confundir representante com representação. 0 representante é sempre da ordem do significante ( simbólico) , assim como a representação é da ordem do signo (imaginário). 0 falo, como representante da fal ta de um significante, é o significante do desejo. É a escrita do sintoma - S(A) - que indica a articulação entre o campo do Outro e o sujeito como barrados.

Cabe, agora, a pergunta: qual o significante que vem do campo do Outro representar o falo como ausência? É o Nome-do-Pai. A função desse significante é inscrever o significante Um ( $\mathrm{S}_{1}$, Significante-mestre), enquanto um conjunto de traços ( traço unário) que marcam a singularidade de um sujeito em um corpo vivo recém-chegado ao mundo. 0 Nome-do-Pai como significante vem no lugar da ausência de outro significante ( falo) para imprimir a marca que irá dar origem ao nascimento de um sujeito barrado eà inauguração do desejo. A substituição de um significante por outro, dando lugar à significação, não é o que constitui a fórmula da metáfora? O Nome-do-Pai é metáfora da Lei como representante do Outro, assim como o falo é metáfora do Nome-do-Pai como desejo da Mãe.

Se o falo, como significante primordial, funda a diferença sexual sob o fundo de uma ausência - não há o significante do Outro sexo - , logo tudo que se fala e que se escreve se sustenta na impossibilidade de se escrever a relação sexual.

Lacan insiste em repetir de diversas maneiras que a relação sexual é impossível e que não cessa de não se escrever. No falo está a origem de tudo o que não se pode abarcar como todo.

Lacan, numa entrevista à televisão, que foi publicada em francês, no ano de 1974, diz: “'Digo semprea verdade: não toda, porque dizê-la toda não se consegue. Dizê-la todaé impossível, material mente: faltam as palavras. Éjustamente por esse impossível que a verdade provém do real." (LACAN, 1993, p.11). Se o falo vem do real para ser simbolizado pelo Nome-do-Pai no campo do Outro, logo ele se situa no limiar entre o real e o simbólico. Do real como impossível ao significante do desejo, ele se desloca continuamente sob a cadeia significante, fazendo com que 0 sujeito não pare de tecer relações com os significantes. 0 efeito dessa tecelagem éa produção de metáforas e de metonímias, deixando, como vestígio do real, um resto não simbolizável.

A chave que abriria as portas da PLENITUDE, isto é, da tal FELICIDADE - "épreciso dizê-lo, ninguém sabe o queé" ( LACAN, 1992, p. 69.) - éo que não há. Eis outra face da castração.

O sujeito é causado pelo significante em função de outra causa que éo real. Justamente por isso éno real que devemos encontrar a origem simbólica do sujeito.

Lacan, em 1961-62, no Seminário 9, L'identification, diz que no real só podemos "entrever" o sujeito como uma "coisa viva sendo", como uma existência excluída 
de qualquer sentido e, justamente por isto, nada podemos falar dessa existência, porque esbarramos no muro erguido pela linguagem. Nada podemos falar, mas podemos supor em só-depois que esse corpo era pura substância gozante, porque o que foi arrancado dessa substância por ação do significante retorna sob a forma de falta-a-gozar. Mas, se essa " coisa viva" se engancha num seio, não está mais só. É no corte dessa solidão que do vivo pode advir um sujeito cujo estatuto ésimbólico.

Lacan, no Seminário 4, A relação de objeto (1956-1957), perguntando como seria esse corte que marca a entrada do significante no mundo - a chegada do Espírito Santo - , responde quea morte é o suporte, a base, a operação pela qual o significante existe. Essa entrada do significante, que só pode ser concebida de forma mítica como uma experiência de morte, não só arranca uma parte da substância gozante do corpo, mas também realiza a separação entre corpo e gozo, fazendo com que, a partir daí, o significante se interponha como limite e como obstáculo à plenitude de gozo.

Esse corte operado pelo significante aponta para o que de real há no gozo e, como tal, fica excluído do simbólico. Quando um corpo vivo émarcado, no campo do Outro (A), pelo significante Um, produz-se a primeira metáfora, que irá dar origem a um sujeito barrado e ao desejo. 0 efeito dessa afirmação primordial pelo significante (falicização) é resultado do recalque originário. 0 real que foi recalcado pelo significante retorna para se articular ao desejo como falta do objeto e ao gozo como o que falta-a-gozar. Engendram-se, assim, as modalidades do objeto a como causa desejante e como mais-gozar.

Se, por um lado, para haver desejo, é necessária a universal ização do gozo fálico, isto é, para todos há a função fálica; por outro lado, o significante introduz um limite intransponível ao gozo, já que a partir dele um corpo, por ter se apartado do gozo, não pode nunca mais gozar por inteiro.

Justamentepor isso, o gozo a queo falantetem acesso édenominado defálico, quer dizer, gozo cerceado pelo significante. Porém, Lacan afirmaquenos delíriospsicóticose nos discursos místicos, temos o testemunho de um gozo para além do falo.

Sem dúvida, Lacan elaborou uma teoria sobre o gozo que demanda uma leitura. Não é objetivo desse artigo, nem minha intenção como autora, apresentar essa leitura, até porque ainda estou rastreando as diversas modalidades de gozo, agrupadas na dicotomia falo e para além do falo. Apresento, então, al gumas coordenadas, como resultado dos estudos que venho fazendo nessa direção.

\section{GOZOFÁLICO}

1. Gozo do órgão, gozo sexual, orgasmo:

“(...) o que chamamos de gozo sexual é marcado, dominado, pela impossibilidade deesta belecer (...) esseúnico U m quenosinteressa, o Um darelação sexual." (LACAN, 1982, p.15) 
"O gozo fálico é o obstáculo pelo qual o homem não chega, eu diria, a gozar do corpo da mulher, precisamente porque o de que ele goza é do gozo do órgão." (LACAN, 1982, p.15)

2. Suposição de um gozo-a-mais:

“( ...) se houvesse um outro gozo que não fálico, não teria que ser aquele”. (LACAN, 1982, p. 81)

3. Outra satisfação:

"( ...) o gozo de que depende essa outra satisfação se baseia na linguagem". (LACAN, 1982, p. 71)

“( ...) uma outra satisfação, a satisfação da fala” ( LACAN, 1982, 87);

4. Gozo suplementar, gozo das mulheres, gozo dos falantes que se alinham do lado do não-todo:

“(...) por ser não-toda, ela [mulher] tem, em relação ao que designa de gozo, a função fálica, um gozo suplementar. (...) eu disse suplementar. Se tivesse dito complementar, aonde é que estaríamos! Recairíamos no todo." (LACAN, 1982, p. 99)

5. Gozo de saber:

"Ali, no gozar, a conquista desse saber se renova de cada vez que ele é exercido, e o poder que ele dá, resta sempre voltado para seu gozo." (LACAN, 1982, p. 130)

“( ...) Pois a fundação de um saber é que o gozo do seu exercício é o mesmo do da sua aquisição." (LACAN, 1982, p. 131)

\section{GOZO PARA ALÉM DO FALO}

“Há um gozo, (...) gozo do corpo (...) para além do falo." (LACAN, 1982, p. 100)

1. Gozo do Outro, Gozo d'A Mulher, gozo do corpo do Outro, gozo feminino, gozo sem limite, gozo que vige na psicose:

“Esse Outro, se só há um apenas, bem que deve ter al guma relação com o que aparece do outro sexo." (LACAN, 1982, p. 93)

"Há um gozo dela, desse ela que não existe e não significa nada." ( LACAN, 1982, p. 100)

"A mulher tem relação com o significante desse Outro, na medida em que, como 
Outro, ele só pode continuar sendo sempre Outro. (...) É por isso que esse significante, (...) marca o O utro como barrado - S(A)." (LACAN, 1982, p. 109)

“( ...) E por que não interpretar uma face do Outro, a face de Deus, como suportada pelo gozo feminino." (LACAN, 1982, p. 103)

2. Gozo do ser, gozo da beatitude:

“( ...) o ser é gozo do corpo como tal, quer dizer, assexuado." (LACAN, 1982, p. 15)

“( ...) há gozo do ser." (LACAN, 1982, p. 96)

“( ... ) e tudo que é para o bem do nosso ser será, por isso, gozo do Ser Supremo, quer dizer Deus". ( LACAN, 1982, p. 96)

“O ser (...) é o ser da significância ( ...) do ser da significância no gozo, no gozo do corpo." ( LACAN, 1982, p. 96)

"A relação do ser ao ser (...) converge para com o cristianismo, para o qual trata-se de beatitude." (LACAN, 1982, p. 199)

"A abordagem do ser, não é aí que reside o extremo do amor, o verdadeiro amor? (...) o verdadeiro amor desemboca no ódio." (LACAN, 1982, p. 201)

3. Gozo místico, "jaculações místicas":

“( ...) eles entrevêem, eles experimentam a idéia de que deve haver um gozo que esteja mais além. É isto que chamamos os místicos." (LACAN, 1982, p. 102)

Espero ter demonstrado que as inclusões do real e do sujeito na estrutura não só assinalam um corte sem costura entre a psicanálise e a lingüística, mas também nos levam às reflexões em torno do gozo, isso que se inscreve no corpo na ordem do excesso, introduzindo a morte na vida e se contrapondo ao desejo como ato de desejar.

Enfim, se o sujeito tem sua origem no real e sua causa no significante, o que resta ao homem? Parodiando Fernando Pessoa, navegar em direção à linha do horizonte e não viver neste mundo à deriva do gozo como se fosse "besta sadia" e "cadáver adiado que procria" ( PESSOA, 1977, 76).

Recebido em 13/ 8/ 2001. Aprovado em 22/ 2/ 2002. 


\section{BIBLIOGRAFIA}

ARRIVÉ, M. (1994) Lingüística e psicanálise, São Paulo, Edusp.

BENVENISTE, É. (1988) Problemas de Lingüística Geral, Campinas, Universidade Estadual de Campinas, 2 v.

CÂMARA JR. (1986) Dicionário de Lingüística e Gramática, 13 ed., Rio de Janeiro, Vozes.

FREUD, S. (1973) "Mas allá del principio del placer", in Obras completas, 3 ed., Madri, Biblioteca Nueva, 3 v.

(1921) "Psicologia de las massas y analisis del yo".

(1917) "Duelo y melancolia".

GODEL, R. (1957) Les sources manuscrites du cours de linguistique générale de F. Saussure, Genebra, Droz, Paris, Minard.

GUINSBURG, J. (org.) (1978) Círculo Lingüístico de Praga, São Paulo, Perspectiva.

JAKOBSON, R. (s.d.) Linguística e comunicação, São Paulo, Cultrix.

LACAN, J. (1998) Escritos, Rio de Janeiro, Jorge Zahar.

Zahar. (1985) 0 seminário, livro 4, A relação de objeto, Rio de Janeiro, Jorge - (1999) 0 seminário, livro 5, As formações do inconsciente, Rio de Janeiro, Jorge Zahar.

Zahar. (1992) 0 seminário, livro 8, A transferência, Rio de Janeiro, Jorge (1961-1962) Seminário 9, L'identification. Inédito.

(1988) 0 seminário, livro 11, Os quatro conceitos fundamentais da psicanálise, Rio de Janeiro, Jorge Zahar.

Inédito.

(1970-1971) Seminário 18, D’un di scours qui ne serait pas du semblant.

Zahar.

(1982) 0 seminário, livro 20, Mais ainda, Rio de Janeiro, Jorge

(1993) Televi são, Rio de Janeiro, Jorge Zahar.

MILNER, J-C. (1987) 0 amor da língua, Porto Alegre, Artes Médicas.

NANCY, J-L \& LABARTHE-LACOUE, P. (1991) 0 título da letra, São

Paulo, Escuta.

PESSOA, F. (1977) Obra poética, Rio de Janeiro, Aguilar.

SAUSSU RE, F. (s.d.) Curso de Lingüística Geral, 10 ed., São Paulo, Cultrix.

Nadiá Paulo Ferreira

Rua Barão daTorre, 206/ 101

22411-000 Rio de Janeiro RJ

Tel. (21) 2267-2931/2522-2176

nadiap@ centroin.com.br 